\title{
LIGHT QUALITY IN THE IN VITRO INTRODUCTION OF Corymbia HYBRID CLONES ${ }^{1}$
}

Denys Matheus Santana Costa Souza ${ }^{2 *}$, Aloisio Xavier ${ }^{3}$, Wagner Campos Otoni ${ }^{4}$, Natane Amaral Miranda ${ }^{5}$ and Joane Helena Maggioni ${ }^{6}$

\footnotetext{
${ }^{1}$ Received on 27.05.2018 accepted for publication on 10.10.2018.

${ }^{2}$ Universidade Federal de Lavras, Programa de Pós-Graduação em Engenharia Florestal, Lavras, MG-Brasil. E-mail: $<$ dmscsouza@gmail.com>.

${ }^{3}$ Universidade Federal de Viçosa, Departamento de Engenharia Florestal, Viçosa, MG-Brasil. E-mail: <xavier@ufv.br>.

${ }^{4}$ Universidade Federal de Viçosa, Departamento de Biologia Vegetal, Viçosa, MG-Brasil.. E-mail: <wcotoni@gmail.com>.

${ }^{5}$ Universidade Federal Rural do Rio de Janeiro, Instituto de Floresta, Seropédica, RJ-Brasil. E-mail: < nataneamaral@gmail.com>.

${ }^{6}$ Universidade Federal de Viçosa, Programa de Pós-Graduação em Engenharia Florestal, Viçosa, MG-Brasil. E-mail: <joane.mgg@gmail.com>.

*Corresponding author.
}

\begin{abstract}
Micropropagation via axillary bud proliferation is recommended for rejuvenation or reinvigoration of selected clones, as well as for improving clonal seedlings rooting. The success of a micropropagation protocol depends on the in vitro introduction, since following phases, multiplication, elongation, and rooting can only take place once the aseptic crop with vegetative vigor has been established. This study aims to assess the effect of light on the in vitro introduction of hybrid clones of Corymbia torelliana x C. citriodora e Corymbia citriodora $\mathrm{x}$ C. torelliana by the micropropagation technique through proliferation by axillary buds. The ministumps, suppliers of explants for in vitro introduction, were conducted in semi-hydroclonal mini-clonal hedge. Nodal segments from three Corymbia torelliana x C. citriodora (TC01, TC02 e TC03) clones and one Corymbia citriodora $\mathrm{x}$ C. torelliana (CT01) clone were collected, disinfested and inoculated in JADS culture medium, in order to compare the effects of light quality from a dark/fluorescent lamp, a fluorescent lamp, and white and red/blue LEDs. At 30 days after inoculation, the following characteristics were evaluated: average contamination percentage, oxidation, non-reactive explants, shoot length and average number of shoots per explant greater than $0.5 \mathrm{~cm}$. Gathered data showed that the use of red/blue LED light source obtained the best results in all assessed characteristics in the in vitro introduction.
\end{abstract}

Keywords: In vitro propagation;Vegetative propagation; LEDs.

\section{QUALIDADE DE LUZ NA INTRODUÇÃO IN VITRO DE CLONES HÍBRIDOS DE Corymbia}

\begin{abstract}
RESUMO - A micropropagação via proliferação de gemas axilares tem sido recomendado para rejuvenescimento/ revigoramento de clones selecionados, e consequentemente melhoria no enraizamento de mudas clonais. O sucesso de um protocolo de micropropagação depende da fase de introdução in vitro, visto que as etapas seguintes de multiplicação, alongamento e posterior enraizamento, só podem ser executadas após o estabelecimento de culturas assépticas e com bom vigor vegetativo. Diante disso, o presente estudo teve como objetivo avaliar o efeito da qualidade de luz na introdução in vitro de clones híbridos de Corymbia torelliana $x$ C. citriodora e Corymbia citriodora $x$ C. torelliana pela técnica de micropropagação via proliferação por gemas axilares. As mini-stumps, fornecedoras dos explantes para introdução in vitro, foram conduzidas em minijardim clonal semi hidropônico. Segmentos nodais de três clones de Corymbia torelliana x C. citriodora (TC01, TC02 e TCO3) e de um clone de Corymbia citriodora $x$ C. torelliana (CT01) foram coletados, desinfestados e inoculados em meio de cultura JADS, à fim de comparar os efeitos da qualidade da luz de Escuro/lâmpada fluorescente, Lâmpada fluorescente, LEDs branco e LEDs vermelho/azul, e. Aos 30 dias após a inoculação, foram avaliadas as-características: porcentagem média de contaminação, oxidação, explantes não reativos, comprimento
\end{abstract}


de brotos e o número médio de brotações por explante maiores que 0,5 cm. Com base nos resultados obtidos, o uso da fonte de luz LEDs vermelho/azul obteve os melhores resultados, para todas as características avaliadas na introdução in vitro.

Palavras-Chave: Propagação in vitro; Propagação vegetativa; LEDs.

\section{INTRODUCTION}

Micropropagation through proliferation of axillary buds has been recommended for rejuvenation of selected clones in a forest area, mainly aiming at improving the production process of cloning. Success of a micropropagation protocol depends on the phase of in vitro introduction, given that the subsequent stages of multiplication, lengthening, and rooting can only be carried out after the establishment of aseptic cultures and with vegetative vigor (George et al., 2008; Trueman et al., 2018).

In recent years, research on vegetative propagation of the genus Corymbia has increased significantly. As a result, micropropagation methods have improved, maximizing clonal production, especially by vegetative rejuvenation (Wendling et al., 2014a,b). Several technologies have been proposed to automate the process, among them: innovations in environment culture, such as alternative containers allowing gas exchanges; new light sources based on LEDs; and automation of cropping systems and routine procedures operations, such as medium preparation, transplanting and acclimatization (Bianchetti et al., 2017).

Recent studies have shown how different qualities of light influence plant metabolism (Batista et al., 2018). Here, the use of a source with a blue (450 - $495 \mathrm{~nm})$ and red $(620-750 \mathrm{~nm})$ lighting that acts on in vitro morphogenesis, plant growth, and development (Gupta and Jatothu, 2017).

The use of light-emitting diode (LED) lamps for plants seems to be advantageous in relation to fluorescents, since LEDs can provide light more efficiently, through particular points in the light spectrum, acting in a larger energy production by photosynthesis (Bugbee, 2016). LED lights have recently become the predominant light source for micropropagation use in plant growth rooms, mainly due to the variation in spectral light composition in the growing environment optimizing the growth of several plant species, becoming an alternative for replacement of cold white fluorescent lamps (Singh et al., 2015).

Revista Árvore. 2018;42(6):e420604
Considering the importance that the Corymbia genus and its hybrids currently represent for the forest sector, obtaining an efficient and reproducible protocol for vegetative propagation will be essential to establish rational conditions for the propagation of these plants. This knowledge will greatly contribute to the commercial production of clonal seedlings in forestry companies, producers and research institutions, to consolidate the basis of commercial forestry.

In this context, the present study aims to evaluate the effect of light quality on the in vitro introduction of hybrid clones of Corymbia torelliana $\mathrm{x}$ C. citriodora and Corymbia citriodora x C. torelliana by the micropropagation technique through proliferation of axillary buds.

\section{MATERIALAND METHODS}

\subsection{Study location and experimental material}

Experiments were conducted at the Tissue Culture Laboratory II of the Institute of Applied Biotechnology for Agriculture-BIOAGRO, Federal University of Viçosa - UFV, located in the municipality of Viçosa/MG.

The material used to obtain the explants came from ministumps of three hybrid clones of Corymbia torelliana $\mathrm{x}$ C. citriodora (TC01, TC02, TC03) and one of Corymbia. citriodora $\mathrm{x}$ C. torelliana (CT01), originating from the CMPC - Celulose Riograndense Company, located in the Guaiba/RS municipality.

The mini-stumps were established in mini-clonal hedge, under a semi hydroponic system of sand canals, in the Research Vivarium of the Department of Forestry Engineering of the Federal University of Viçosa, Viçosa/ MG. The plants received nutrient solution from a dripping system, applied four times a day, in a total daily flow of $4 \mathrm{~L} \mathrm{~m}^{-2}$. The nutrient solution was composed of calcium nitrate $\left(920 \mathrm{mg} \mathrm{L}^{-1}\right)$, potassium chloride $\left(240 \mathrm{mg} \mathrm{L}^{-1}\right)$, potassium nitrate $\left(140 \mathrm{mg} \mathrm{L}^{-1}\right)$, monoammonium phosphate (96 $\left.\mathrm{mg} \mathrm{L}^{-1}\right)$, magnesium sulfate (364 mg L-1), hydrofiber $\left(40 \mathrm{mg} \mathrm{L}^{-1}\right)$, boric acid $\left(2,800 \mathrm{mg} \mathrm{L}^{-1}\right)$, zinco sulfate $\left(0.480 \mathrm{mg} \mathrm{L}^{-1}\right)$, manganês sulfate $\left(1,120 \mathrm{mg} \mathrm{L}^{-1}\right)$, 
copper sulfate $\left(0,100 \mathrm{mg} \mathrm{L}^{-1}\right)$ and sodium-molybdate $\left(0,040 \mathrm{mg} \mathrm{L}^{-1}\right)$. The electrical conductivity of the nutrient solution was maintained around $2.0 \mathrm{mS} \mathrm{m}^{-2}$.

\subsection{Explant collection and preparation}

Buds were gathered (Figure 1A) from the ministumps second (first introduction) and fourth collection (second introduction), 60 and 120 days after the apex pruning, respectively. Nodal segments measuring between 3 and $4 \mathrm{~cm}$ were prepared by removing the leaves from the third and fourth nodes, from the apex of the shoots (Figure 1B). Subsequently, the explants were immersed in autoclaved deionized water and transported to the tissue culture laboratory. During the whole process, the equipment used was disinfected with $70 \%(v / v)$ alcohol solution.

\subsection{In vitro introduction}

The nodal segments were washed five times in running water and immersed in fungicidal solution containing $2.4 \mathrm{~g} \mathrm{~L}^{-1}$ of Orthocide $500^{\circledR}(50 \%$ as active principle) for 15 minutes. They were washed five times in autoclaved deionized water and immersed in $70 \%$ (v/v) alcohol solution for 30 seconds with constant shaking, within the horizontal laminar flow chamber. They were then immersed in $1 \%(\mathrm{v} / \mathrm{v}) \mathrm{NaOCl}$ solution

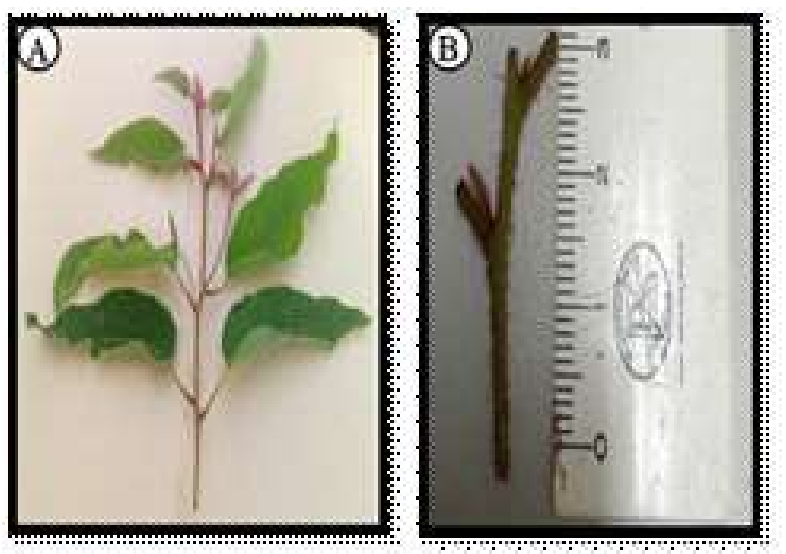

Figure 1 - Preparation of the explants of Corymbia hybrid clones for in vitro: (A) fresh budding of the ministumps, highlighting the portion used to obtain the explants; (B) nodal segment.

Figura 1- Preparo dos explantes de clones hibridos de Corymbia para introdução in vitro: (A) brotação recém coletada das mini-stumps, destacando a porção utilizada como explantes; (B) segmento nodal. and Tween 20 ( 3 drops $/ 100 \mathrm{ml}$ solution) for 15 minutes. Finally, the nodal segments were washed in 5-fold autoclaved deionized water and inoculated vertically, under aseptic conditions, into $15 \mathrm{~cm}$ x $2.5 \mathrm{~cm}$ test tubes containing $10 \mathrm{ml}$ of culture medium.

The time from the collection of explants under field conditions until the inoculation in culture medium was less than three hours. The explants were kept immersed in autoclaved deionized water to avoid dehydration, from collection to inoculation.

The culture medium used was JADS (Correia, 1995) supplemented with $0.5 \mathrm{mg} \mathrm{L}^{-1} \mathrm{BA}$ (6-benzyladenine Sigma Co), $0.1 \mathrm{mg} \mathrm{L}^{-1} \mathrm{ANA}\left(100 \mathrm{mg} \mathrm{L}^{-1}\right.$ naphthaleneacetic - Sigma Co ) acid myo-inositol (Sigma Co), $800 \mathrm{mg}$ $\mathrm{L}^{-1}$ of PVP30 (Polyvinylpyrrolidone - Synth Ltda), $30 \mathrm{~g}$ $\mathrm{L}^{-1}$ of sucrose (Synth Ltda) and $6 \mathrm{~g} \mathrm{~L}^{-1}$ of agar (Merck S.A.). The $\mathrm{pH}$ of the solution was adjusted to $5.8 \pm$ 0.05 with $\mathrm{NaOH}(0.1 \mathrm{M})$ and $\mathrm{HCl}(0.1 \mathrm{M})$ prior to autoclaving and agar addition. Autoclaving of the culture medium was performed at a temperature of $121^{\circ} \mathrm{C}$ and a pressure of approximately $1 \mathrm{kgf} \mathrm{cm}^{-2}$ for 20 minutes.

Three hybrid clones of Corymbia torelliana $\mathrm{x} C$. citriodora (TC01, TC02, TC03) and one Corymbia. citriodora $\mathrm{x}$ C. torelliana (CT01) were used to make two in vitro introductions.

\subsection{Light sources}

After inoculation, the explants were kept in growth room at $25 \pm 2{ }^{\circ} \mathrm{C}$ for a photoperiod of 16 hours, and irradiance of $80 \mathrm{imol} \mathrm{m}^{-2} \mathrm{~s}^{-1}$ (quantified by radiometer, LI - COR ${ }^{\circledR}$, LI-250A Light Meter). Three different light sources were tested: fluorescent lamp (HO Sylvania T12, 110 W, São Paulo, Brasil), white LED lamp (SMD 100, 18 W, Vilux ${ }^{\circledR}$, Vitória, ES, Brasil) and red/blue LED lamp (LabPARLL-HR / DB-480, 11,6 W, LabLumens ${ }^{\circledR}$, Carapicuíba, SP, Brasil). As a control, the explants were kept for seven days in the dark and afterwards transferred to the fluorescent lamp (HO Sylvania T12, 110 W, São Paulo, Brasil). Light spectra were obtained by spectroradiometer (Ocean Optics Spectra-Suite, Ocean Optics, Dunedin, FL) (Figure 2).

\subsection{Design and experimental evaluations}

The experiment was conducted in a $4 \times 4$ factorial arrangement, in a completely randomized design, with four clusters of Corymbia hybrids (three hybrid clones of Corymbia torelliana x C. citriodora (TC01, TC02, 


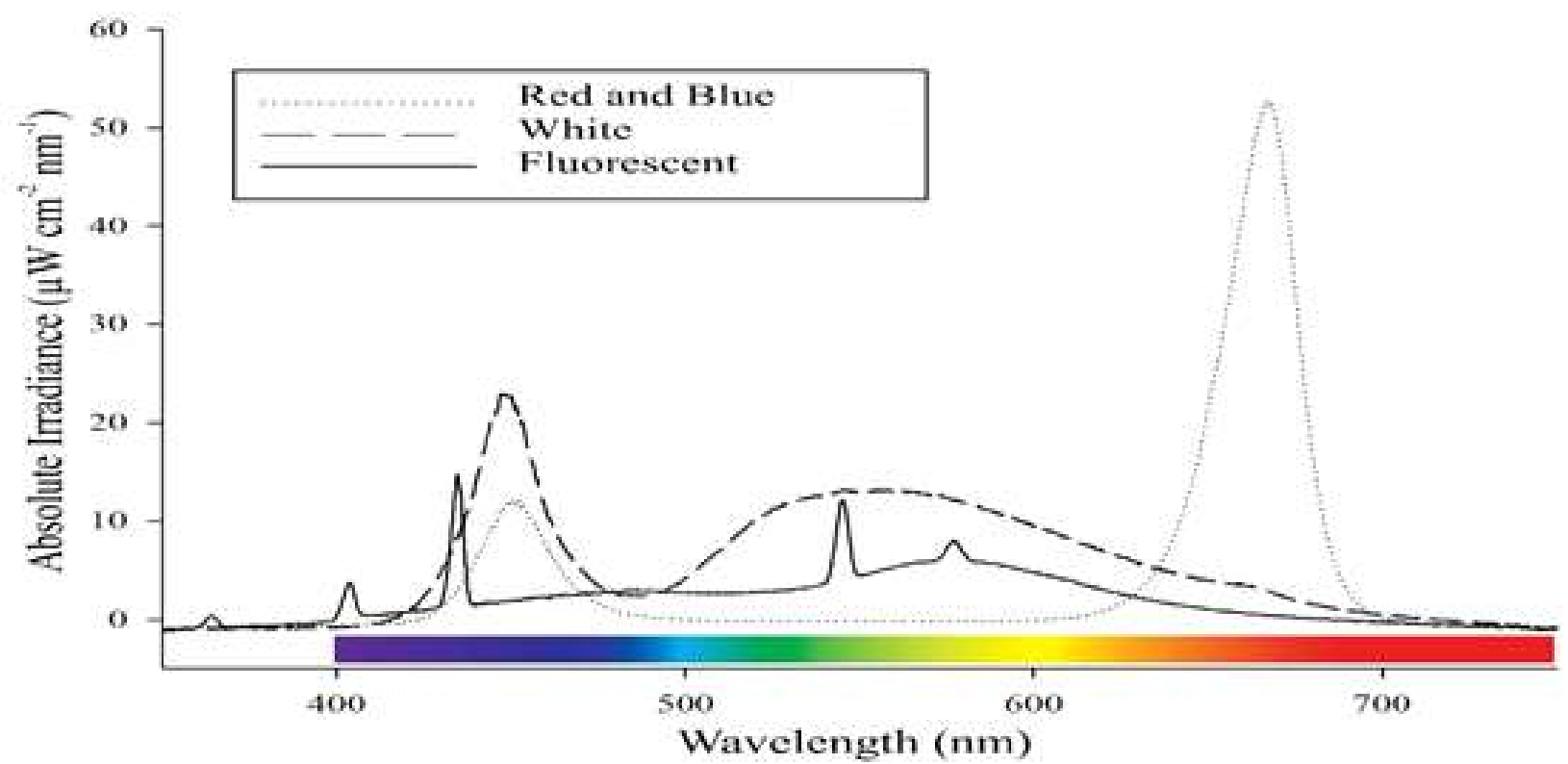

Figure 2 - Variations of absolute irradiance (iW cm-2 nm-1) and wavelength (nm) of light emitted by fluorescent lamps (HO Sylvania T12, $110 \mathrm{~W}$ ), white LEDs (Vilux® SMD 100, $18 \mathrm{~W}$ ) and red / blue LEDs (LabPAR LL-HR / DB$480,11.6 \mathrm{~W}$ ) used in induction experiments on explants in the in vitro condition of Corymbia hybrid clones obtained in the LCT-II growth room, BIOAGRO / UFV.

Figura 2 - Variações da irradiância absoluta $\left(\hat{i} \mathrm{~W} \mathrm{~cm}^{-2} \mathrm{~nm}^{-1}\right)$ e do comprimento de onda (nm) da luz emitida pelas Lâmpadas fluorescentes (HO Sylvania T12, $110 \mathrm{~W}$ ), LEDs brancos (Vilux ${ }^{\circledR}$ SMD 100, $18 \mathrm{~W}$ ) e LEDs vermelho/ azul (LabPAR $L L-H R / D B-480,11,6 \mathrm{~W})$ utilizadas na experimentação de indução em explantes na condição in vitro de clones híbridos de Corymbia, obtidas na sala de crescimento do LCT-II, BIOAGRO/UFV.

TC03) and one of Corymbia citriodora x C. torelliana (CT01)) and four sources of light: Dark/Fluorescent Lamp (E/LF), Fluorescent Lamp (L/F), LED Lamp white (L/B and red/blue (V/A) with four replicates, composed of plots with eight explants.

At 30 days after inoculation, the following characteristics were evaluated: average percentage of contamination, oxidation, non-reactive explants, shoot length and average number of shoots per explant greater than $0.5 \mathrm{~cm}$.

\subsection{Data analysis}

The analysis was processed in software $\mathrm{R}$, version 3.0.3 (R Core Team, 2014), using the ExpDes package, version 1.1.2 (Ferreira et al., 2013). Data from the two subcultures at the in vitro introduction phase were averaged. The variables contamination, oxidation, nonreactive explant, length and number of shoots were not normally distributed with a test of Shapiro-Wilkem at $5 \%$ of significance. For significant variables, the Tukey test was done at 5\% significance.

\section{RESULTS}

The appearance of the Corymbia hybrid clone explants in the in vitro introduction, regarding studied characteristics, is shown in Figure 3.

The characteristics of contamination, oxidation and shoot length of the observed explants presented their factors (clone and light source) acting independently. Regarding the number of nonresponsive shoots and explants, the factors had a significant interaction.

The hybrid clones of Corymbia torelliana x $C$. citriodora (TC01, TC02 e TC03) and Corymbia citriodora $\mathrm{x} C$. torelliana (CT01) had the lowest average contamination percentage $(5.46 \%)$ with the $\mathrm{red} / \mathrm{blue}$ LED (Figure 4A). No significant difference ( $p>0.05)$ was observed when clones were compared (Figure 4B).

The same tendency was observed regarding the phenolic oxidation of the explants, in which the red/blue LED lights promoted the lowest average of $2.34 \%$ (Figure 4C). The values in each clone were very similar (Figure 4D), and there was no significant difference $(\mathrm{p}>0.05)$.

Revista Árvore. 2018;42(6):e420604 


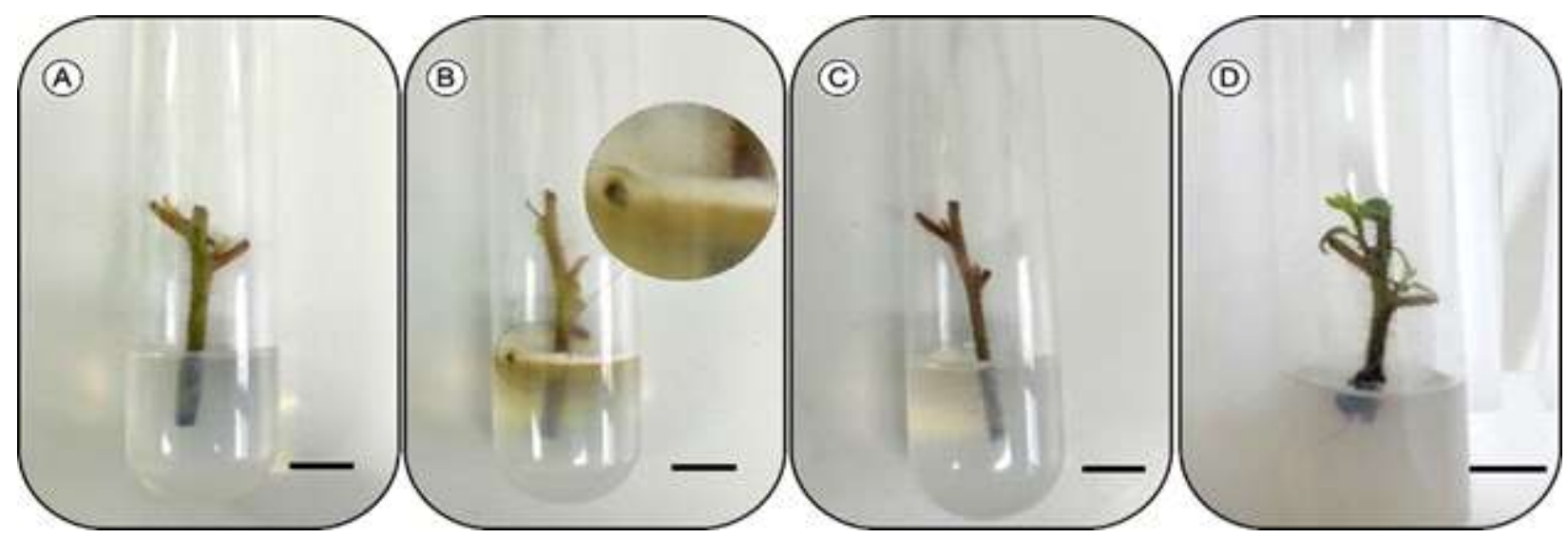

Figure 3 - Explants of Corymbia hybrid clones, at 30 days after inoculation in vitro condition: (A) nonresponsive explant; (B) contaminated explant; (C) oxidized explant; (D) reactive explant. Bar $=1 \mathrm{~cm}$.

Figura 3 - Explantes de clones híbridos de Corymbia, aos 30 dias após a inoculação na condição in vitro: (A) explante não responsivo; (B) explante contaminado; (C) explante oxidado; (D) explante reativo. Barra $=1 \mathrm{~cm}$.

The combination of red/blue LEDs was determinant for the lower percentage of contamination and oxidation, independent of analyzed clones. On the other hand, the highest contamination percentages and phenolic oxidation were obtained with the dark/fluorescent lamp.

Varied behavior was observed regarding shoots longer than $0.5 \mathrm{~cm}$., with significant differences $(\mathrm{p}<0.05)$ found both in clones and light sources.

The shoots (mean $>0.5 \mathrm{~cm}$ ) from explants exposed to red/blue LED treatment showed longer lengths (average $1.02 \mathrm{~cm}$ ), than those exposed to fluorescent lamp and dark/fluorescent lamp. No significant difference was observed between this group and that of white LED (Figure 4E).

Among the clones analyzed, clone (TC03) was statistically different regarding sprout length (mean $0.98 \mathrm{~cm}$ ) than clone (TC02) and clone (TC01) (Figura 4F), whereas, when compared with clone (CT01), it showed no significant difference.

As for the number of shoots larger than $0.5 \mathrm{~cm}$ per explant, the data was significantly different $(p<0.05)$ under different treatments of light sources, as well as for clones.

Overall, the red / blue and white LEDs showed results that provided the highest numbers of shoots, resulting in a higher number of shoots per explant (2.03 and 2.11) (Figure 5A).
Data on the percentage of non-responsive explants showed a significant effect $(\mathrm{p}<0.05)$ under different light sources, as well as clones. Regarding the response process in the induction of shoots in the explants, at 30 days after inoculation, low percentages of explants without buds were obtained, where clones (CT01) and (TC03) were the most responsive, reaching $100 \%$ in $\mathrm{red} /$ blue LEDs. Other treatments had similar results and no significant difference was found.

For the best light source among the clones, the clone (CT01) with red/blue LED light obtained smaller percentages of nonresponsive explants, differing statistically only for fluorescent lamp. However, clone (TC03) also had the lowest mean of non-responsive explants in detriment of the use of red/blue LEDs, with statistical difference from the dark/fluorescent lamp. The values were very close to the other clones, with no difference between the light sources.

The light source had direct influence on the development of Corymbia hybrid clone explants, where red/blue LED lights provided the best results based on lower oxidation, contamination, length, number of shoots and reactive explants.

\section{DISCUSSION}

The light source used in the in vitro explant cultivation had a direct influence on contamination of hybrid clones of Corymbia torelliana x C. Citriodora e Corymbia citriodora $\times$ C. torelliana. The red/blue 

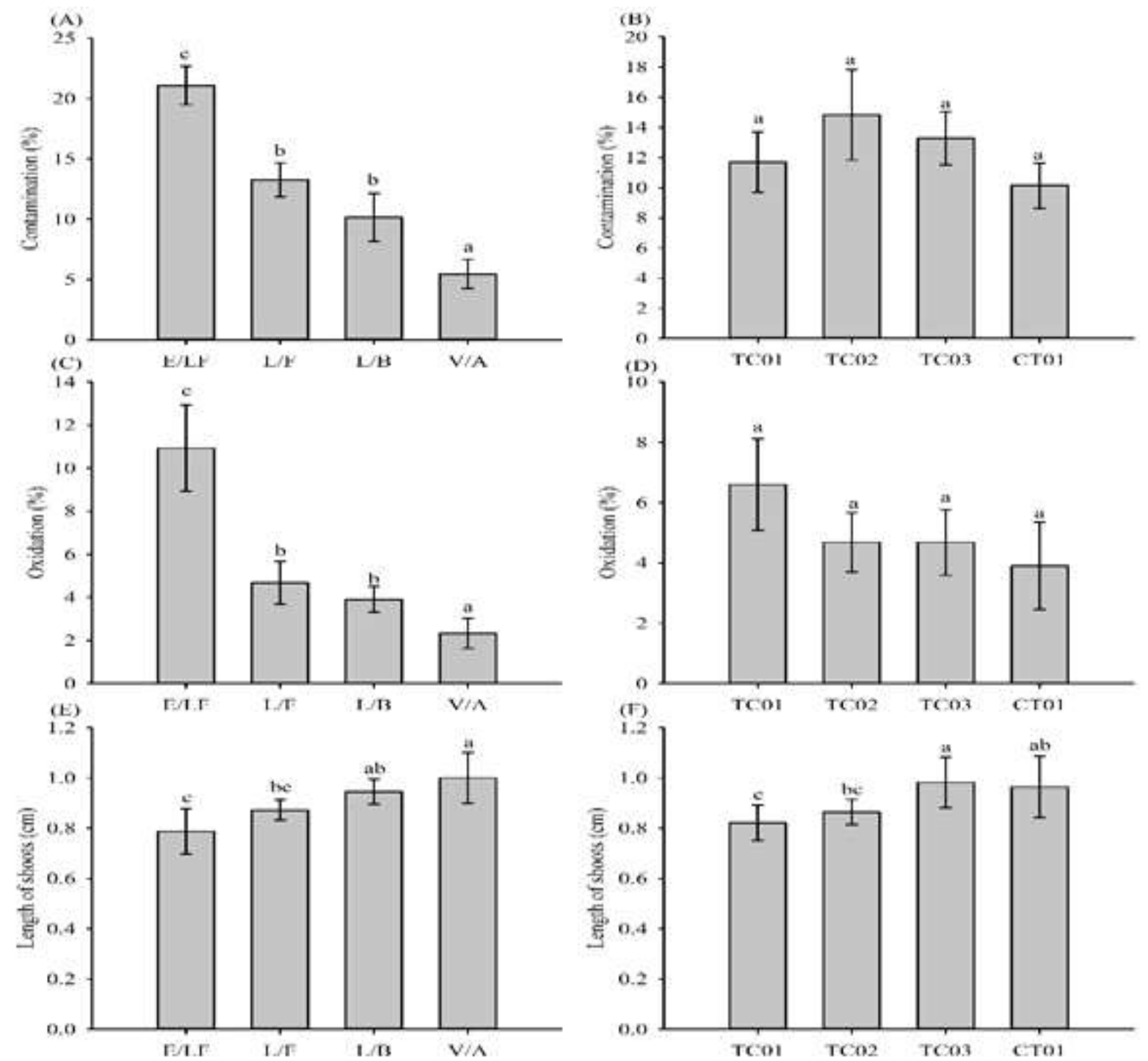

Figure 4-Characteristics observed in the in vitro introduction according to the different sources of light Dark/fluorescent lamp (E / LF), Fluorescent lamp (L/F), white LEDs (L/B) and red / blue (V/A) LEDs and clones hybrids of Corymbia torelliana $\mathrm{x}$ C. citriodora (TC01, TC02 and TC03) and Corymbia citriodora $\mathrm{x}$ C. torelliana (CT01). (A) Percentage of contamination due to different light sources; (B) Percentage of contamination as a function of the hybrid clones; (C) Percentage of oxidation as a function of different light sources; (D) Oxidation percentage as a function of hybrid clones (E) Length of shoots according to different light sources; (F) Length of shoots according to the hybrid clones. *Averages followed by the same letter do not differ from each other, by the Tukey test at $5 \%$ probability.

Figura 4-Características observadas na introdução in vitro em função das diferentes fontes de luz Escuro/lâmpada fluorescente (E/LF), Lâmpada fluorescente (L/F), LEDs branco (L/B) e LEDs vermelho/azul (V/A) e clones híbridos de Corymbia torelliana $x$ C. citriodora (TCO1, TC02 e TC03) e Corymbia citriodora $x$ C. torelliana (CTO1). (A) Porcentagem de contaminação em função das diferentes fontes de luz; (B) Porcentagem de contaminação em função dos clones hibridos; (C) Porcentagem de oxidação em função das diferentes fontes de luz; (D) Porcentagem de oxidação em função dos clones híbridos (E) Comprimento das brotações em função das diferentes fontes de luz; (F) Comprimento das brotações em função dos clones híbridos. *Médias seguidas de uma mesma letra não diferem entre si, pelo teste de Tukey a $5 \%$ de probabilidade.

Revista Árvore. 2018;42(6):e420604 


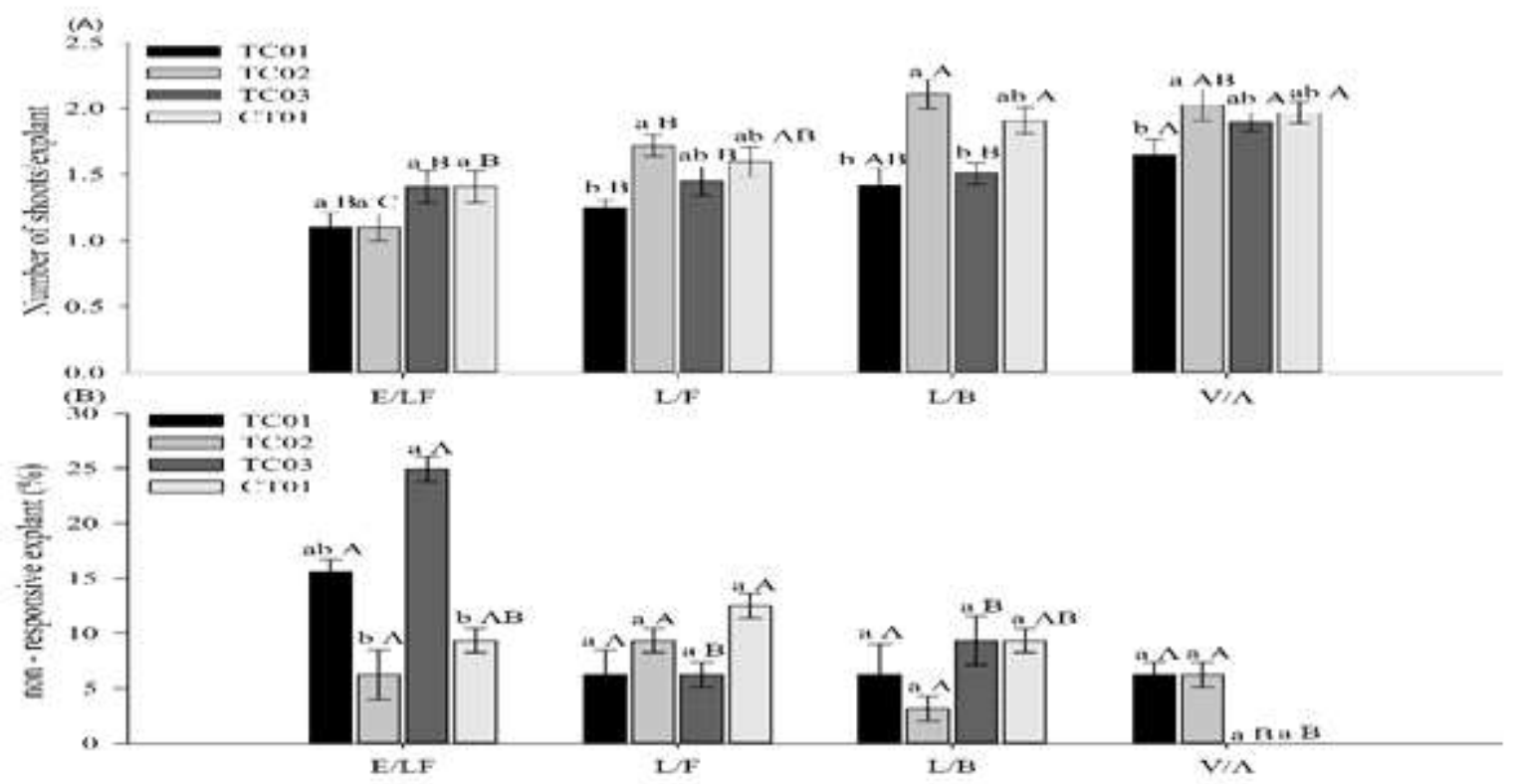

Figure 5-Characteristics observed in the in vitro introduction according to the different sources of light Dark / fluorescent lamp (E/LF), Fluorescent lamp (L/F), white LEDs (L/B) and red / blue (V/A) LEDs and clones hybrids of Corymbia torelliana $\mathrm{x}$ C. citriodora (TC01, TC02 and TC03) and Corymbia citriodora x C. torelliana (CT01). (A) Number of shoots per explant; (B) Percentage of nonresponsive explant. Lower case letters establish the comparison between clones and upper case letters represent the comparison between light sources. *Averages followed by the same letter do not differ from each other, by the Tukey test at $5 \%$ probability.

Figura 5 -Características observadas na introdução in vitro em função das diferentes fontes de luz Escuro/lâmpada fluorescente (E/LF), Lâmpada fluorescente (L/F), LEDs branco (L/B) e LEDs vermelho/azul (V/A) e clones híbridos de Corymbia torelliana x C. citriodora (TC01, TCO2 e TC03) e Corymbia citriodora $x$ C. torelliana (CTO1). (A) Número de brotos por explante; (B) Porcentagem de explante não responsivo. Letras minúsculas estabelecem a comparação entre os clones e letras maiúsculas representam a comparação entre as fontes de luz. *Médias seguidas de uma mesma letra não diferem entre si, pelo teste de Tukey a $5 \%$ de probabilidade.

LED light provided the best responses, due to the lower percentage of contamination in relation to the other evaluated treatments.

According to Kurtzman and Martínez-Carrera (2013), several organisms with influence of blue and red lights absorb photons and transduce the energy into the cells regulating the fungal photoresponses through differential genetic expression, in the carotenoid biosynthesis. Thus, the metabolic pathway of microorganisms such as fungi can be regulated by light, mainly in the production of secondary metabolites with specific wavelength requirements, showing maximum activity at 440-470 $\mathrm{nm}$ (Postemsky and Curvetto, 2016).

Low intensity regarding clone response to phenolic oxidation was observed, especially those under red/ blue LEDs. These results are similar to those found by Oliveira et al. (2015), who obtained less than $6 \%$ phenolic oxidation in the in vitro establishment of Eucalyptus cloeziana explants.

Phenolic oxidation has been a problem associated with the micropropagation of woody species and has been reported in several studies (Brondani, 2011; Oliveira et al., 2015; Oliveira et al., 2017). These results may be related to internal environmental factors that affect explant development, where smaller flasks tend to exhibit reduced concentrations of carbon dioxide and high concentrations of ethylene, but may also be affected by irradiation, air temperature and relative humidity (Xiao et al., 2011).

In shoots longer than $0.5 \mathrm{~cm}$, light quality has been found to affect the development of Corymbia hybrid clones, with significant changes regarding sprouting. Wavelengths with light spectra in the red and blue range acted with greater effectiveness in 
morphogenesis. The use of LED bulbs in in vitro cultures has been shown to be advantageous for the regulation of physiological development processes such as photomorphogenesis, leading to higher quality, production and development of micropropagated plantlets (Batista et al., 2018).

The flexibility of combining the wavelengths of the LEDs for photoreceptors can provide a higher production of metabolites, influencing morphogenesis and in vitro growth (Li et al., 2013; Postemsky and Curvetto, 2016). However, responses may vary according to species.

In this study, a variation between clones and light sources was observed in the in vitro introduction. Data found in the literature were similar to these results, showing that the combination of red/blue LEDs induced a higher number of shoots per explant in Dendrobium officinale and Ajuga multiflora (Li et al., 2013; Jeong and Sivanesan, 2018). These authors reported that LEDs are an effective alternative, especially during the in vitro regeneration of shoots. According to Hung et al. (2015), the red/blue ratio of LEDs significantly influenced the in vitro response of Brassica chinensis seedlings, where red LEDs strongly stimulated shoot production per explant. In this context, Bugbee (2016) considered the LED light source advantageous for micropropagation as an alternative for replacement of fluorescent lamps.

Following the same pattern of the other characteristics studied, the average number of nonresponsive explants varied between clones and light sources. In general, it was observed that the clones had high rates of explants with response to shoot induction (between $75 \%$ and $100 \%$ of responsive explants). This allows continuing the multiplication phase, highlighting the importance of high induction rates. Although some explants were not responsive, some remained alive, evident by their green coloration (Erig and Schuch, 2005).

In a hybrid of Eucalyptus urophylla $\mathrm{x}$ E. globulus and globulus, $95 \%$ of explants with shoots was obtained (Borges, 2011). In contrast, Oliveira et al. (2015) obtained a $51.2 \%$ average of Eucalyptus cloeziana explants with shoots. Thus, different results are observed for nonresponsive explants in the in vitro introduction phase, with varying responses according to the plant material (genotype) and the culturing conditions used.

Revista Árvore. 2018;42(6):e420604
According to Trueman et al. (2018), for the success of micropropagation it is necessary that only some explants emit shoots free of contamination, because the beginning of in vitro propagation is the main limiting phase. However, when a large amount of micropropagated material is required, higher rates of bud explants may be required to rapidly increase the amount of material produced.

\section{CONCLUSIONS}

Based on the results obtained in this study, which used hybrid clones Corymbia torelliana $x$ C. Citriodora (TC01, TC02, TC03) e Corymbia citriodora $x$ C. torelliana (CT01), it can be concluded that, due to the methodology adopted for the proliferation of axillary buds, the red/ blue LED light source is the most adequate for in vitro introduction, having a direct influence over the development of the explants of Corymbia hybrid clones, considering: 1) a lower rate of oxidation, contamination and non-responsive explant; 2) greater shoot length and number of shoots per explant.

\section{ACKNOWLEDGEMENTS}

The CNPq (Conselho Nacional de Desenvolvimento Científico e Tecnológico, Brasil), FAPEMIG (Fundação de Amparo à Pesquisa do Estado de Minas Gerais), and CAPES (Coordenação de Aperfeiçoamento de Pessoal de Ensino Superior) for financial support. The BIOAGRO (Instituto de Biotecnologia Aplicada à Agropecuária) for provision of laboratory infrastructure. The CMPC (Celulose Riograndense) for financial support and genetic material.

\section{REFERENCES}

Batista DS, Felipe SHS, Silva TD, Castro KM, Rodrigues TCM, Miranda NA, et al. Light quality in plant tissue culture: does it matter? In Vitro Cellular and Developmental Biology - Plant. 2018;54(3):195-215.

Bianchetti RE, Resende CF, Pacheco VS, Dornellas FF, Oliveira AMS, Freitas JCE, et al. An improved protocol for in vitro propagation of the medicinal plant Mimosa pudica L. African Journal of Biotechnology. 2017;16(9):418-28.

Borges SR, Xavier A, Oliveira LS, Melo LA, Rosado A.M. Enraizamento de miniestacas de clones híbridos de Eucalyptus globulus. Revista Árvore. 2011;35(3):425-34. 
Brondani GE, Dutra LF, Wendling I, Grossi F, Hansel FA, Araujo MA. Micropro-pagation of an Eucalyptus hybrid (Eucalyptus benthamii $\mathrm{x}$ Eucalyptus dunnii). Acta Scientiarum. Agronomy. 2011;33(4):655-63.

Bugbee B. Toward an optimal spectral quality for plant growth and development: the importance of irradiation capture. Acta Horticulturae.

2016;1134:1-12.

Correia D, Gonçalves AN, Couto HZ, Ribeiro MC. Efeito do meio de cultura líquido e sólido no desenvolvimento de gemas de Eucalyptus grandis $\mathrm{x}$ Eucalyptus urophylla na multiplicação in vitro. IPEF. 1995(48/49):107-16.

Erig AC, Schuch MW. Estabelecimento in vitro de Mirtilo a partir de segmentos nodais. Scientia Agrária. 2005;6:91-6.

Ferreira EB, Cavalcanti PP, Nogueira DA. ExpDes: Experimental Designs package. R packageversion 1.1.2. 2013 .

George EF, Hall MA, Klerk GJ. Micropropagation: uses and methods. In: Plant propagation by tissue culture. Dordrecht: Springer; 2008. 1-64.

Gupta SD, Jatothu B. Fundamentals and applications of light emitting diodes (LEDs) in vitro plant growth and morphogenesis. Plant Biotechnology Reports. 2013;7:211-20.

Hung CD, Hong CH, Jung HB, Kim SK, Ket NV, Nam MW, et al. Growth and morphogenesis of encapsulated strawberry shoot tips under mixed LEDs. Scientia Horticulturae. 2015;194:194-200.

Jeong BR, Sivanesan I. Impact of light quality and sucrose on adventitious shoot regeneration and bioactive compound accumulation in Ajuga multiflora Bunge. Scientia Horticulturae. 2018;236:222-8.

Li HM, Tang C, Xu Z. The effects of different light qualities on rapeseed (Brassi ca napus L.) plantlet growth and morphogenesis in vitro.
Scientia Horticulturae. 2013;150:117-24.

Kurtzman JRRH, Martínez-Carrera D. Light, what it is and what it does formycology. Micologia Journal. 2013;25:23-33.

Oliveira C, Goldbach JD, Bettencourt GMF, Amano E, Franciscon L, Quoirin M. Micropropagation of Eucalyptus grandis $\mathrm{x}$ E. urophylla AEC 224 clone. Journal of Forestry Research. 2017;28:29-39.

Oliveira LS, Brondani GE, Piotto KDB, Calsavara R, Gonçalves AN, Almeida M. Micropropagation of Eucalyptus cloeziana mature trees. Australian Forestry. 2015;78:219-31.

Postemsky PD, Curvetto NR. In vitro studies of secondary metabolite-related responses in some species of genus Grifola (Agaricomycetes) from Argentina. International Journal of Medicinal Mushrooms. 2016;18(4):355-63.

R Core Team. R: A language and environment for statistical computing. Vienna: R Foundation for Statistical Computing; 2014.

Singh D, Basu C, Wollweber MN, Roth B. LEDs for energy efficient greenhouse lighting. Renewable and Sustainable Energy Reviews. 2015;49:139-47.

Trueman SJ, Hung CD, Wendling I. Tissue culture of Corymbia and Eucalyptus. Forests. 2018;9:84.

Wendling I, Trueman SJ, Xavier A. Maturation and related aspects in clonal forestry - part I: concepts, regulation and consequences of phase change. New Forests. 2014a;45:449-71.

Wendling I, Trueman SJ, Xavier A. Maturation and related aspects in clonal forestry - part II: reinvigoration, rejuvenation and juvenility maintenance. New Forests. 2014b;45:473-86.

Xiao Y, Niu G, Kozai T. Development and application of photoautotrophic micropropagation plant system. Plant Cell, Tissue and Organ Culture. 2011;105:149-58. 